\title{
SBB Negative
}

National Cancer Institute

\section{Source}

National Cancer Institute. SBB Negative. NCI Thesaurus. Code C162079.

An indication that a sample does not have detectable Sudan black B staining. 